\title{
CMAJ 2011 election survey: home/palliative care
}

$\mathrm{T}$ he Canadian Home Care Association estimates that public outlays on home care in Canada are about $\$ 5.8$ billion per year. There is no known estimate of private outlays for home care, although the Health Council of Canada has estimated that in the neighbourhood of 500000 Canadians are tending ailing relatives. The level of private spending, though, has never been quantified. Some families spend on the order of thousands of dollars annually for medical supplies and equipment, while others shell out between $\$ 30000-\$ 60000$ per year to hire private services.

One thing is certain, though - there is no sign that spending by Canadians on home care will abate any time in the near future.

A slew of campaign trail promises related to home care, meanwhile, might suggest that major support for families providing home care or major changes in Canadian policies, programs and strategies are in the offing.

The promises have included a Conservative party proposal to increase nonrefundable tax credits for family caregivers (www.budget.gc.ca/2011/plan /Budget2011-eng.pdf), a Liberal Party vow to provide financial relief for family caregivers through employment insurance and tax benefits, and a New Democrat promise to enshrine home care as a medically necessary service under the Canada Health Act. But experts warn that what has actually been promised is either altogether meager or somewhat lacking in detail (www.cmaj.ca/cgi/doi/10.1503/cmaj .109-3856).

Party responses to a home care question in CMAJ's 2011 election survey marked no departure, as they confined their responses to very general commitments, or ones focused primarily on providing a modest measure of tax assistance to families to care for their loved ones (see below).

Therein lies an unspoken truism about most political responses to what

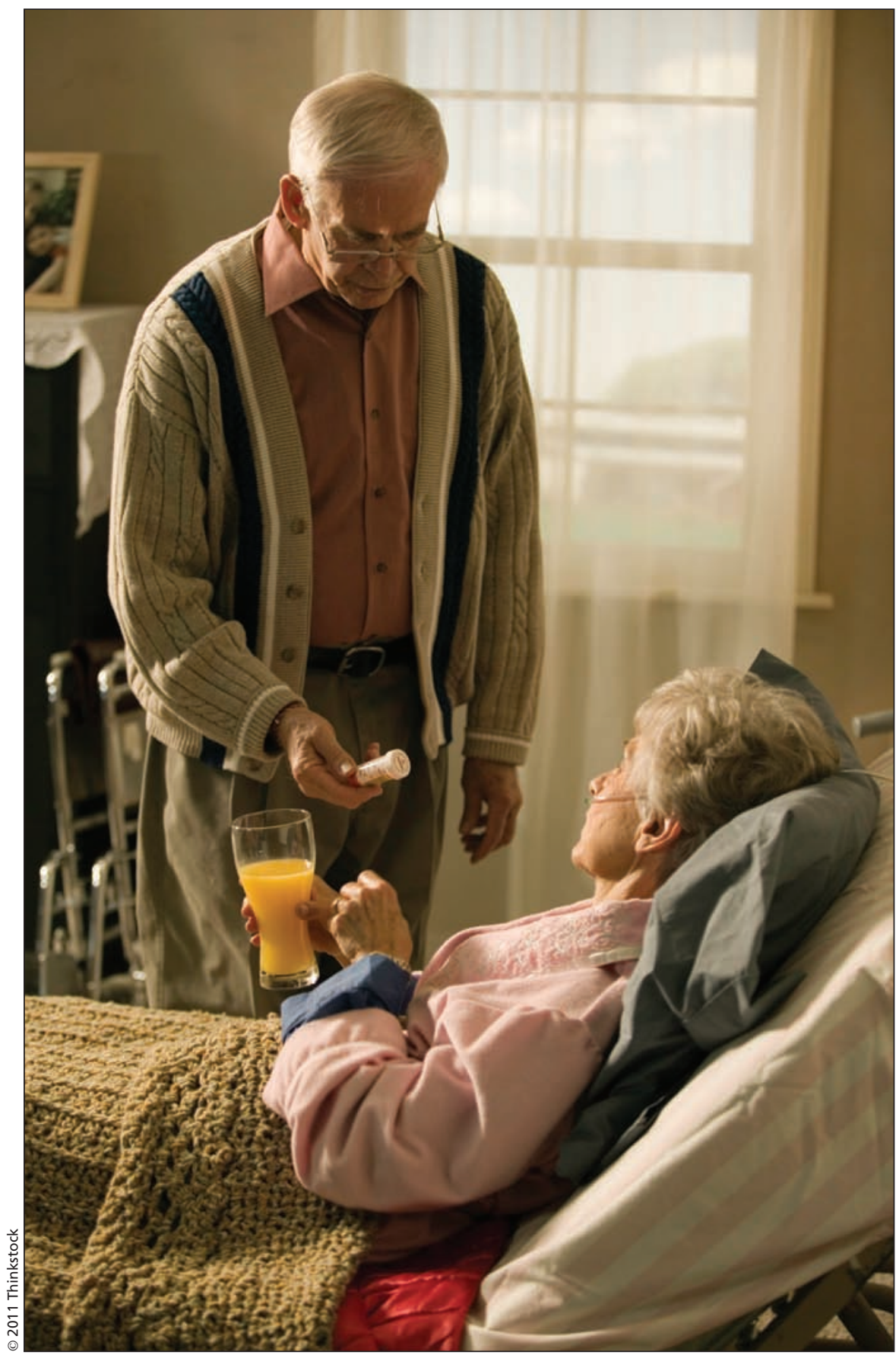

The Canadian Home Care Association says that an increasing amount of home care is being provided by a senior citizen caring for a spouse.

many have called Canada's looming crisis in home care. Rather than focus on policies and programs aimed at bolstering services that assist families in the provision of home care, governments and political parties are more prone to making very modest gestures of tax support and thereafter, washing their hands of the issue. It's tantamount to an admission that governments view home care 
as primarily the responsibility of families, or at a minimum, want to offload both the bulk of costs and the burden of care onto the backs of Canadians.

"The biggest challenge with all these programs that the political parties are talking about right now is that it's probably the lowest hanging, easiest fruit that they are going after," i.e, those families who can afford to hire private help, says Nadine Henningsen, executive director of the Canadian Home Care Association.

But the reality is that home care is increasingly being provided by a senior citizen caring for a spouse "and a tax credit or an insurance benefit is not going to cut it for them," she adds.

"It's one fifth of the solution," Henningsen says, arguing the needs of home care providers are far more complex and include such things as: respite services through adequate access to nurses, therapists and other health support workers; access to information about how to actually provide appropriate care; and ready access to professional medical help and services as required.

From that perspective, the election promises to date, while welcome, are "like a drop in the ocean" of home care, Henningsen adds.

"There is no simple solution," she says. But that solution will have to include greater integration of home care into the broad spectrum of health care services, with resources "following the patient."

Instead, patients are simply offloaded from acute care or long-term care beds, which are promptly filled up by other patients, with no real savings to the system.

"If we could flow that money a little bit better, I think the system would work out better," Henningsen says. "Home care really makes its biggest impact by adding just a little bit of service for a frail senior so that they can live in their home, rather than going to a long-term care facility."

There are only vague inklings of such integration in some of the party responses to the CMAJ survey. The Liberals say they will work with the provinces and territories in the negotiation of a new health accord to ensure that there aren't "significant variations" in home and palliative care services across the country. The provinces now spend an average of $4.2 \%$ of their health budgets on home care but that ranges from as low as $1 \%$ to as high as $7 \%$, according to the Canadian Home Care Association.

In their response, the New Democrats say that if elected, they would create designated federal transfer payments to the provinces for both home and long-term care but offered little detail. The Conservatives declined participation in the survey, while the Bloc Québécois argued that health is provincial jurisdiction, that the province of Québec has already moved to establish an integrated palliative care network, and that the feds should tend to their own health clients (aboriginal peoples and veterans), while increasing unconditional transfer payments to Québec. - Wayne Kondro, CMAJ

Survey question: What measures/programs would your party introduce in response to Canada's home care/palliative care crisis?

\section{Conservative response:}

No response. Rather than participate in CMAJ's 2011 election survey, the Conservatives forwarded a weblink to their party platform. Asked what the rationale was for declining participation, party spokesperson Ryan Sparrow says the weblink constitutes a response to the survey. "That response is the response from the campaign."

\section{Liberal response:}

"Responding to the pressures faced by Canadian families grappling with the financial and emotional strains of home care and palliative care is at the core of the Liberal platform.

A Liberal government will act immediately to deliver direct support to Canadians who care for elderly or seriously ill loved ones at home. The Liberal Plan for Family Care includes a Family Care Employment Insurance Benefit, allowing Canadians to take six months off work to care for loved ones without having to quit their jobs, and a Family Care Tax Benefit of up to $\$ 1,350$ a year to help low- and middle-income family caregivers manage the costs.

With the federal-provincial-territorial Health Accord expiring in 2014, a Lib- eral government will be at the table for Canadians. Two specific areas will also be priorities for a Liberal government: home care services and drug coverage. With more and more patient care taking place at home rather than in the hospital, we'll work with provinces and territories to ensure that Canadians in different parts of the country don't face significant variations in drug coverage, and home care services, including priority areas like mental health and palliative care."

\section{New Democrat response:}

"Jack Layton and the New Democrats will establish a new designated federal home care transfer to guarantee a basic level of home care services to all Canadians wherever they live. The NDP will also, initiate a new designated federal long-term care transfer to begin addressing the shortage of quality care spaces across the country. We will take further action to double the funding for forgivable loans under the Home Adaption for Seniors' Independence program (HASI) to help seniors remain in their own homes. Finally a New Democrat government will introduce an Inter-generational Home Forgivable Loan Program, modeled on a Manitoba Government initiative, to help up to 200,000 families a year retrofit their homes to create self-contained secondary residences for senior family members. Families will be eligible for a forgivable loan to cover 50 per cent of the costs of a renovation up to a maximum of $\$ 35,000 . "$

\section{Bloc Québécois response:}

"Le Bloc Québécois est préoccupé par les enjeux liés à la santé et aux services sociaux, dont ceux d'améliorer la qualité des soins afin que les Québécoises et les Québécois puissent bénéficier de services adéquats dans des délais raisonnables.

Toutefois, la santé et les services sociaux sont des domaines de compétence qui relèvent exclusivement du Québec et des provinces et, à ce titre, le Bloc Québécois juge que le Québec et les provinces sont les mieux à même de mettre sur pied des systèmes de soins de santé qui répondent adéquatement aux besoins de leur population respective selon les modalités qu'ils déterminent et ce, sans conditions de la part du gouvernement fédéral.

Le Bloc Québécois juge que la cor- 
rection complète du déséquilibre fiscal qui sévit au Canada et qui prive le Québec et les provinces des revenus nécessaires pour remplir leurs responsabilités en santé et pour les services sociaux, permettra au Québec et aux provinces de développer davantage les services à leur population dans leurs champs de compétences exclusifs, avec les partenaires présents sur leur territoire et de s'assurer qu'en matière de santé et de services sociaux, leurs citoyennes et citoyens reçoivent les soins adéquats en temps opportun.

Comme vous le savez sûrement, le Québec a adopté, depuis une quinzaine d'années, une série de positions et de politiques publiques sur des soins de fin de vie de qualité: le Programme québécois de lutte contre le cancer (1998), la Politique en soins palliatifs de fin de vie (2004), les Normes en matière de soins palliatifs pédiatriques (2006) et le Plan directeur du développement des compétences des intervenants en soins palliatifs (2008). Ces politiques visent notamment à mettre en place un réseau intégré de soins palliatifs pour répondre aux besoins de la population québécoise.

Bref, bien que le Bloc Québécois encourage le gouvernement fédéral à développer des programmes en soins palliatifs pour venir en aide à sa propre clientèle (autochtones, anciens combattants, etc.), il préconise des crédits d'impôt et des transferts sans conditions qui pourraient permettre au Québec de met- tre sur pied des programmes pour venir en aide à sa population."

CMAJ 2011. DOI:10.1503/cmaj.109-3876

Editor's note: Fourth of a series of stories on CMAJ's 2011 election survey:

Part 1: Health transfers

(www.cmaj.ca/cgi/doi/10.1503/cmaj .109-3865)

Part 2: Pharmacare

(www.cmaj.ca/cgi/doi/10.1503/cmaj .109-3870)

Part 3: Health human resources (www.cmaj.ca/cgi/doi/10.1503/cmaj .109-3875) 